\title{
Carbon sequestration potential in community managed forests in Nepal
}

Volume 2 Issue 8 - 2017

\section{Opinion}

Garrett Hardin's (1968) theory about "the tragedy of the commons" has come to symbolize the degradation of the environment to be expected whenever many individuals use a scarce resource. Each man is locked into a system for compelling him to increase his herd without limit. Ruin is the destination toward which all men rush, each pursuing his own best interest in a society that believes in the freedom to use the commons. The consequence is more damage and tragedy starts. Aristotle long ago observed that "what is common to the greatest number has the least care bestowed upon it. Everyone thinks chiefly of his own, hardly at all of the common interest". The overuse of resources (e.g. forest timber and firewood shortages, water resource depletion, overgrazing, overfishing, etc.) and polluting or degrading the environment (acid rain, use of agro-chemicals, waste dumping, carbon dioxide discharges and global warming) are some examples of tragedy of commons. The forest resource as common pool resource, its depletion contributes to the environmental degradation and consequence is global warming, whereas its enhancement functions just reverse to this. The collective action is significantly essential to stepping toward the better forest resource management. Agrawal and Ostrom stated that, the coalition of actors in forest management respecting the local knowledge and have been playing a vital role to add in work efficiency to halt deforestation and forest degradation and restore degraded resource. Share management responsibility with either local communities or a range of stakeholders plays a vital role in forest management. The management of common property resources requires collective action. There are several examples of collective actions applied for forest protection, which work effectively to motivate for we-feeling. Some of them are, the Chipko (to stick) movement by Sundarlal Bahuguna in 1970 in Uttar Pradesh; the Arabari experiment by Dr. Ajit Banerjee in the early 1980s in West Bengal in India and community plantation by Dr. Tejendra Bahadur Singh Mahat in Thokarpa village of Sindhupalchok district, Nepal before 1961. Without community's effort, it was impossible to stop the contractors to harvest trees in Uttarpradesh and Bangladesh. Similarly, the open lands, which were claimed by Biratabal (traditional land owners), were possible for plantation because of the common efforts of local community. In this way, the community participation has started as a collective action to manage the forest resource in Nepal. Community Managed forest is adding the value through carbon sequestration. If the people care to protect the forest, this is the name and respect of collective action because the care is impossible without the common interests of group of individuals. Ultimately, the theory of collective action is applied in community managed forests like community forest, collaborative forest, public plantation and community planted forests etc in Nepal. The communities have themselves been participating in the preparation of the plan, which includes the protection of the forest, utilization of the forest products and development of the forests. So, they have effectively been implementing the community forest plan to manage the forest. On the other hand, they have been applying their indigenous knowledge and skill. Around $20 \%$ of the world's forests are de-facto owned and/or managed by communities. Notably, $70 \%$ of the forest area is the legal property of communities in

\author{
Ram Asheshwar Mandal \\ Central Department of Botany, Theory of Commons and \\ Participatory Forest Management, Nepal \\ Correspondence: Ram Asheshwar Mandal, Central \\ Department of Botany, Theory of Commons and Participatory \\ Forest Management, Kirtipur, Nepal, Tel 984-145-056-4, \\ Email ram.mandal@gmail.com
}

Received: October 26, 2017 | Published: December 22, 2017

Mexico. About $30 \%$ of the forests are managed under the community forest in Nepal. In this context, community forest management regime has been performing the best examples of carbon sequestration which is potential for certified emission reduction under the Reducing Emission from Deforestation and Forest Degradation (REDD).

\section{Examples of carbon sequestration potential}

There are good examples of carbon sequestration potential especially in community managed forests like public plantations (PP) and community planted forests (CPF) in Nepal. The studies done public plantations (PP) specifically Shreepur, Banauta and Bisbitty public plantations (PP) while community plated forests (CPF) particularly, Sita, Jogikuti and Ramnagar, Nepal are managed based on the principle of community managed forests where the forests users develop and implement the plan themself. The result showed the highest carbon sequestration $19.82 \mathrm{t} \mathrm{ha}^{-1}$ in Shreepur public plantation (PP) while it was the lowest only $4.60 \mathrm{t} \mathrm{ha}^{-1}$ in Ramnagar CPF among these planted forests. The total estimated carbon sequestration was $176.38 \mathrm{t}$ in Shreepur PP. In the same trend, the other higher records of carbon sequestration were found 17.80, 13.64 and $11.00 \mathrm{t} \mathrm{ha}^{-1}$ annually in Banauta PP, Bisbitty PP and Sita CPF respectively, so the total carbon sequestration were $131.73,85.93$ and $47.52 \mathrm{t} \mathrm{ha}^{-1}$ in these plantations correspondingly. However, low record of carbon sequestration was found $6.34 \mathrm{t} \mathrm{ha}^{-1}$ in Jogikuti CPF so the total carbon sequestration was found 46.22. Lastly, the total carbon sequestration was $17.07 \mathrm{t}$, which was the lowest in Ramnagar CPF. Similarly, the projection of carbon sequestration for plantations also showed different in the forests. Here, the estimated cumulative carbon sequestration potentials in public plantation and community planted forests could be 1210.38 $\mathrm{t}$ for 2 years, $1815.57 \mathrm{t}$ for 3 years, $2420.76 \mathrm{t}$ for 4 years, $3025.95 \mathrm{t}$ for 5 years and $6051.9 \mathrm{t}$ for 10 years. The estimated values of carbon sequestration $\mathrm{ha}^{-1}$ were found about US\$ 83.99 and 74.85 of Shreepur PP and Banauta PP respectively. Meanwhile, the values of carbon sequestration $\mathrm{ha}^{-1}$ were US\$ 43.84 and 56.53 of Sita CPF and Bisbity PP respectively. Similarly the expected cumulative monetary net value 
of carbon sequestration potential may also be differed in public and community planted forests for every year. Here, the cumulative net value may be US\$ 3362.96 for 2 years, US\$ 8940.33 for 3 years, US\$ 11920.44 for 4 years, US\$ 14900.55 for 5 years and US\$29801.1 for 10 years. Remarkably, it is exciting information for carbon trade in Nepal since Nepal is potential to bring upto US\$ 60 million from carbon fund under the forest carbon partnership facility as the Emission Reduction Plan Idea Note (ER-PIN) got permission to work for REDD+ demonstration activities from REDD+ programme under the World Bank for emission reduction from the forests of Rautahat to Kanchanpur district between 2015 to 2020 . In addition, the report of piloting showed that, the expected monetary value of carbon sequestration ha ${ }^{-1}$ were US\$ 7.59 and $14.60 \mathrm{ha}^{-1}$ in 5 years and in years of Charnawati watershed Dolkha and Lundikhola watershed Gorkha respectively.

\section{Acknowledgements}

I acknowledge professor emeritus Pramod Kumar Jha, Professor Ishwar Chandra Dutta and Professor Siddhi Bir Karmacharya who encouraged to write such opinion.

\section{Conflicts of interest}

The authors are agreed to publish the paper through MOJ Ecology and Environmental Science. This paper is not submitted anywhere else and not published in any journal. There is no conflict of interest.

\section{Funding}

None. 